\title{
From procedural to complex rationality relations: Observed system and observing system
}

\begin{abstract}
ANNE ISLA*
Abstract. - Procedural rationality and substantive rationality call for two different approaches in terms of methodology and epistemology. While in the first case, the question of interest is "what is it made of?" The appropriate methodology is analytic and the epistemology, positivist. In the second case, the question will be "what does it make, and why?" the methodology complex and the epistemology, constructivist. The object of study will be different in both cases. The choice of a methodology also reflects a different view of uncertainty. As a consequence, it is impossible to use simultaneously the two rationality concepts and to study the behavior of an economic agent. How can we then classify the economical theories according to either one of the rationality concept and reasoning approach (complex or analytic)? The Economics of Convention School, developed in France, offers a conceptual framework consistent with a complex approach. It still has to adhere to that complex approach in a more total way, by assuming the economist observer's projects and aims.
\end{abstract}

Classification Codes: B00, B19, B4, B41, N01.

\section{Introduction}

The issue of rationality sends back to the choice of a methodology, and more particularly, to the shift from an analytical methodology to a complex one. Yet, this shift modifies the object of study of the economic sciences. Indeed, it is difficult to change the methodology basis without changing the object of study. It would equally be difficult to complement a market study with an analysis based on the concept of organization, without modifying the methodology principles. The choice of a methodology, either substantive rationality or procedural rationality, will determine the position of the researcher. This latter will be either inside or outside the organization, and will adopt a reasoning approach in terms of either internal market or external.

The shift from substantive rationality to procedural rationality can be done through the connected notions of uncertainty, including probabilistic uncertainty and radical uncertainty. The use of procedural rationality and the related concept of radical uncertainty

\footnotetext{
* Lereps, Université des Sciences Sociales de Toulouse, Manufacture des tabacs, 21 allée de Brienne, 31000 Toulouse, France. E-mail: isla@univ-tlse1.fr

Keywords: Methodology, epistemology, constructivism, complexity, rationality.
} 
refers, to a certain extent, to some of the radical methodology's principles (Descartes), which are replaced with those of the complex methodology (Le Moigne and Morin among others). This process represents the first step into complexity. The second step is expressed by the interiorization of the observer in the analysis. In other words, the observer becomes responsible of his intentions and projects. This rationality will be qualified as a complex one.

To demonstrate that the complex approach does not bring "something more" but "something else" to the economic analysis, it is first necessary to review the two commonly known forms of rationality (Favereau, 1989a): substantive rationality and procedural rationality. We will analyze them as complementary concepts, instead of opposite ones as it is still often done. The concept of uncertainty will also bring another insight to rationality and help us in our demonstration. If we oppose these two forms of rationality, we may end with aporia. It is possible to come up with very sophisticated refinements of the substantive rationality and of the procedural rationality. However, they do not call for the same measurement and do not raise the same problem.

Our demonstration follows four steps. First, the shift from substantive rationality to procedural rationality is shown by using the concept of uncertainty. The concept of substantive rationality is operational under the hypothesis of probabilistic uncertainty. Second, we will make the concept of procedural rationality operational by supposing radical uncertainty. Third, these two concepts are considered to be irreducible as a consequence of the use of the uncertainty hypothesis. Reasoning with procedural rationality represents then the first step towards complexity. Fourth, the next step consists in clarifying the relation between the observing system and the observed system.

\section{From substantive rationality to procedural rationality}

The principle of rationality consists in searching to realize an objective by using the available means in the best way possible. In the standard and increased standard theories ${ }^{1}$, this principle is generally considered to equivalent to optimizing an objective function (utility, profit, cost) with respect to the agent's stock of information and endowments. The chosen methodology of substantive rationality appears through the formalization of the homo oeconomicus' behaviour. In the paradigm of substantive rationality, the economic agents are considered to behave individually and under full rationality in most cases (no context, complete information). Links between agents exist only though trade and markets. An economic agent is equivalent to a "black box". Under these hypotheses, the internal environment of the individual is not important to understand the external environment and the appropriateness of both environments. Under substantive rationality, the decision making process comes to searching for the "best possible" expected

\footnotetext{
${ }^{1}$ We distinguish different categories of standard theories, from increased standard to non standard theories, proposed by Favereau (1989a). What distinguishes standard theories from increased standard theories is the internalization by the second of the organizational forms into the substantive rationality's framework. What distinguishes increased standard theories from non- standard theories is the analysis by the second of organizations and rules under the bounded rationality's hypothesis.
} 
outcomes. The rationality judgement focuses only on the decision, that is the choice is made among pre-existing options (Favereau, 1989b; 1997).

Now, let us review how the paradigm of substantive rationality has been refined in the history of the economic literature.

Analyses based on mathematical modeling does not consider an agent's real behaviour. An agent solves a problem by assigning a probability of success (mathematical expectation) and by choosing the more or less risky scenario. The analysis rather tries to formalize the most rational action plans. The approach is here normative, based on the definition of "what must be", rather than descriptive and trying to describe "what it is" (Weinberg, 1995, for instance). Such an approach allows for the elimination of the dominated strategies, that are strategies which yield to the agent, independently from the other players' decision, a profit lower than the one he can get by adopting another strategy. Nevertheless, if all the players choose dominating strategies, one may end with Pareto under optimal situations. This outcome is illustrated by the prisoner's dilemma. To overcome this problem, Nash proposed, in 1951, a strategy selection criterion, which is stricter than the one based on a simple elimination of some dominant strategies. Nash equilibrium is a combination of strategies chosen in such a way that each player's strategy corresponds to an optimal choice given the other players' strategies.

The concept of Nash equilibrium does not, however, give us any information about the decision making process, that is the procedure adopted by each one of the players to end with the optimal choice given the other players' decisions. Nash's objective was not to understand how players take their decisions to reach the equilibrium situation. The Nash equilibrium only indicates that once the combination of equilibrium strategies is reached, no player has an interest in choosing another strategy. The problem of multiple equilibrium is still not resolved.

Several extensions of the Nash equilibrium have been proposed, principally by repeating the game, by introducing incomplete or imperfect information, that is uncertainty. One can quote the elaboration of notions of perfect equilibrium and of correlated equilibrium in sub-games. Still, the notion of Nash equilibrium does not say anything about the agent's reasoning process, which leads to the outcome. Some theoreticians have then suggested the concept of rationalizable strategy. Let us briefly remind in more details the three extensions of the Nash equilibrium mentioned above.

1 - The solution to the problem of multiple equilibrium can be found by using the notion of perfect equilibrium in sub-games. The game is repeated. The action of a player depends upon what the other players have done on the precedent move. The backward induction allows to draw an unique outcome. Every player is able to evaluate the effect of his decision of the other players' future actions, by assuming their possible decisions and payoffs, and perfect rationality. The problem of backward induction is that it exceeds the agents' reasoning capacity when the situation implies a number of decisions and sequences too important.

The notion of perfect equilibrium in sub-games helps, however, to see how players interact with each other. To characterize rationality in a situation with interactions, we can use the concept of crossed anticipations ( $c f$. Munier and Orléan, 1993, p. 20). The determination of the equilibrium point, resulting from interactions of players, depends on 
how players' anticipations are developed. The collective action requires that each one of the participant recognizes to a certain extent the other players' intention. This approach has led to a narrow and strong notion of common knowledge. An event is a common knowledge for a group of individuals if all know about it, if all know that all know about it, if all know that all know that all know about it... It's a mutual knowing of infinite order (Lewis, 1969). Every player behaves rationally (he is searching for the maximum payoff) and all other players know it. Therefore, each player is aware of the other's strategies and characteristics, of the outcomes resulting from all of the possible combinations of these strategies, and of the individual payoffs associated to each outcome. In other words, the information is perfect.

The theory of games with imperfect information offers a second approach to common knowledge, where players are unaware of the effective values attached to some characteristics of their partners, although they know all of the possible values. There is common knowledge about the set of all possible eventualities only. A player's beliefs are expressed in terms of probabilities.

In games with incomplete information, Harsanyi (1967) suggested the preliminary construction of the notion of "type" in order to organize a player's beliefs into hierarchical classes. Games with incomplete information can then be reduced to games with complete but imperfect information ${ }^{2}$. For this, Harsanyi supposes the existence of a fictive player, called "Nature", whose unique activity consists in attributing a type, that is a set of characteristics, to each one of the players. The other players are unaware of these characteristics, but are aware of all possible types (incomplete information).

2 - A second extension of the Nash equilibrium is proposed through the notion of correlated equilibrium. Players choose, based on random events, a combination of strategies constituting Nash multiple equilibrium. The correlated equilibrium allows to predict a possible outcome to the game given that players communicate before their decision choice, but it does not help to understand how players select the random events used to coordinate their decisions. The decision making process is not explained. Game theorists have given little attention to this aspect of equilibrium selection.

In response to this issue, Schelling (1960) showed that by accessing to contextual data, agents may be able to select a particular equilibrium and coordinate their decisions. By referring to cognitive salience, Schelling argued that precedence is one possible way to come out with focal points. Strategies are in this case conditional onto exogenous random events and not onto the other players. We are talking here about "situated rationality" and, consequently, about a less radical common knowledge. However, one can still build an exhaustive list of all possible events. To make the rationality of beliefs and the arbitrariness of conventions compatible, theorists often call for the concept of selffulfilling prophecy ${ }^{3}$ (Guesnerie, 1989; Chiappori, 1994).

\footnotetext{
${ }^{2}$ Perfect information :successive games ; imperfect information : some moves are simultaneous.

${ }^{3}$ Self-fulfilling prophecy is a class of representations, which are self-achieved as soon as th agents unanimously accept them. The archetype of the phenomenon is the equilibrium of sunspots. Regardless of the "reality" of the phenomenon, agents only need to believe in the influence of sunspots on their economic life, for their beliefs to be confirmed by their action.
} 
3 - A third approach consists in studying the process of convergence based on a priori defined individual rationality. This comes to establishing some reactions' correspondence, or in other words, to defining the concept of rationalizable strategies, or the rules of rationality adapted to different contexts. A strategy will be rationalizable if it is optimal for beliefs, which are consistence with rationality being common knowledge (Bernhein, 1984). There even exists an algorithm to derive rationalizable strategies ${ }^{4}$. In most cases, almost all of the combinations of strategies - if it is not all - are rationalizable, but this approach usually leads to too many solutions (Guerrien, 1997, p. 81). We have to make two new hypotheses : first, the beliefs must be correct, that is at the time when a player chooses his strategy, he has to foresee what the other players will do. If we do not obtain any solution, we can widen the set of choices by supposing that players can play mixed strategies. If we obtain several solutions, we will have to look for more restrictive solution concepts with the help of the notion of perfect equilibria in sub-games.

In these models, besides the huge calculus capacity, which is sometimes asked to the agent, we also assume that the agent can be faced with a set of alternatives. These alternatives are either certain, risky or uncertain (but in this case, the uncertainty is measurable), and the rational choice is totally determined by the player's environmental constraints.

A different approach of substantive rationality is suggested by the evolutionary game theory, in which individuals and strategies are just one, probabilities are replaced by frequencies, and the player's behaviour is determined (by genes...). The aim of "evolutionists" is to draw a more realistic approach compared to the neo-classical approaches discussed previously, thought they refer to the same methodological individualism principle. "For the purposes of economic science, however, the model of rational self-interest individual has serious limitations (...) A realistic and scientific appraisal of human nature (and the degree and nature of self interest manifested therein) is an appraisal supportable by reference to the biological and cultural determinants of contemporary human behaviour and the evolutionary forces that have shaped those determinants" Winter (1994, pp. 616-617). This bounded rationality hypothesis justifies the adoption of routine behaviours.

Uncertainty in evolutionary games can yet be measurable (non-radical) as individual judgements concern only utility. This theory never treats the issue of normal, just or conformed behaviour, and there is no interpretation by the individuals (Orléan, 1997). Human creativity and action still represent the weak parts of this theory (Delorme, 1997). According to these authors, all these shortcomings are a consequence of the

\footnotetext{
${ }^{4}$ In games with normal forms, the rationalizability consists in eliminating by iterations the strictly lower strategies. The set of solutions contains Nash equilibria. In games with more complex forms, it is possible to make a selection among the Nash equilibria (Demange and Ponsard, 1994, p. 229). In these games, the player chooses one among several of the solutions. The process is as follows: if $\mathrm{E}$ is strong, he sends every time $\bar{m}$ because the effect of $\bar{m}$ is a capitulation of R. R knows that. Therefore, if he observes $\bar{m}$, he will conclude that $\mathrm{E}$ is weak and he will fight. E knows that, and if he turns out to be weak, he will send $\bar{m}$. The rationalizable outcome is: E send every time $\bar{m}$, R will capitulate if he observes $\bar{m}$ and will fight if he observes $\bar{m}$ (idem p. 232).
} 
biologic context used to construct evolutionary games. To get interpretations, deliberations, or decision-making processes, it is necessary to adjust the concept of rationality as it is interpreted by evolutionary games by adding new hypotheses about the learning process and the mechanism of trial and error.

To summarize, game theories focus on economic agents' strategies, introduce uncertainty, incomplete and imperfect information. The derived models imply an environment described by mathematical expectations. Future outcomes are then probabilizable. The theory of evolutionary games wishes to underline the "emergence phenomena", but then it is necessary to avoid the possibility to choose its agents.

Modeling is possible if all of the alternatives are known. In this approach, the reasoning model is analytic, and the optimality criterion is adapted to the different behaviours, independently of the cognitive subject. Optimality is indeed the only criterion used to study a behaviour's rationality, while environment is considered as an exogenous constraint for the players ${ }^{5}$. The environment cannot thus be considered as constructed. The conception of scientific knowledge refers, here, to positivism, and the analyses belongs to the substantive rationality approach.

\section{The radical uncertainty in procedural rationality}

The notion of procedural rationality was introduced by Simon. The realization of an aspiration level is substituted to the search of the maximum utility. At the difference of neo-classical models, where all the alternatives are evaluated before being chosen, the model developed by Simon includes a sequential evaluation procedure of the alternatives. The evaluation is conducted as new alternatives are discovered (Simon, 1955, p. 110). That's how he introduced the notion of procedural rationality. A behaviour is substantially rational when it responds to a given objective and a system of constraints, whereas it is procedurally rational when it results from an appropriate deliberation process, and depends on this latter (Simon, 1976, pp. 130-131) ${ }^{6}$.

In the procedural rationality paradigm, deliberation precedes the choice and, by taking into account informational constraints, yields "the best" decision. Decisions are not separated from the decision making process, and the judgment of rationality concerns both decisions and the process: one needs to construct the set of options (Favereau, 1989b; 1997). Deliberation puts together some procedures, which help an agent to adapt his decision making process to his own cognitive limits. We can also add that deliberation contributes to variations of these limits. Relationships between the agents' processes and

\footnotetext{
${ }^{5}$ About the substantive rationality notion, we can refer to Simon (1976, for instance p. 131), and many other recent studies, such as te one by Quinet (1994, especially pp. 154-155).

${ }^{6}$ In her analysis of Simon's work, Quinet showed that a choice is rational because it is a result of deliberation. Only a choice left to fate would be irrational (1994, p. 136). We would like better talk, as Dennett (1978, especially p. 271) about intentionality instead of rationality, but we will not develop this distinction in this article. The work of Conein (1990, pp. 313 and following) may interest those who are interested in this distinction.
} 
their objectives are modified and constantly adapted. The way a problem is expressed becomes an integral part of the decision making process.

As Quinet says (originally from Mongin, 1986), procedural rationality emphasizes deliberation as an exercise of rationality, while optimization in neo-classical theories tends to reduce deliberation to an exercise of calculus.

The subjective, personal and close environment can become the key to rationality. Boyer and Orléan used this concept of rationality in their 1991 article. Contextual elements appear to be important for the logic of decision, and agreements among individuals (even if these agreements come to only trade exchanges) can only be reached within a common framework. In this case, economic activities, as other human activities, have to be considered to belong to an environment ( $c f$. Dewey, 1967, p. 83). The process of apprenticeship represents the realization of this environment and of the problematic situations resulting from agents' interactions (Renault, 1997, p. 36) ${ }^{7}$.

We should then emphasize the relationships which links recursively an individual to the collective levels ( $c f$. Dupuy, 1992, p. 19).

In this context, characteristics of the individual internal environment is important to understand the adequacy between internal and external environments ( $c f$. Pernin, 1994). The concept of internal environment, which represents the whole set of hypotheses, affects in a very important way the decision making process, because it links decision rules to information collection rules, apprenticeship procedures and to psychological and psychosocial theories (Favereau, 1989b).

The procedural rationality paradigm underlines the self-organization of the decision making process, that is the recursive relationships between decisions taken by agents and their decision making process, and in turn between the decision process and the consequences of the action ${ }^{8}$.

Rationality is not evaluated according to the truth of its conclusions, but according to the quality of the procedure it uses. The procedural adjective underlines the constructed character of rationality within a process of non-stop apprenticeship.

Economic agents are given limited rationality, and since they do not have all the information, they have to look for the missing information and to create it ${ }^{9}$.

The concept of limited rationality is sometimes ambiguous in the economic literature. Indeed, it can be part of the substantive rationality paradigm if we take into account only the complexity of its character (i.e. totally counted) and not the complexity ${ }^{10}$ of its environment. As it is underlined by Favereau (1997, p. 49), the passage from rationality based on optimization to bounded rationality (in the full sense of the term) cannot be separated from the passage from substantive rationality (choice between the predetermined solutions) to procedural rationality (construction of the set of solutions).

Bounded rationality can be a modality of omniscient rationality which appears when information is not complete or is imperfect. It can also be analyzed within the framework

\footnotetext{
${ }^{7}$ For detailed analysis of the apprenticeship notion, refer to Isla (1999, p. 12 and following).

${ }^{8}$ Pernin (1998) studies autonomous rationality.

${ }^{9}$ Creating or researching information depends on whether one adopts or not a constructivist perspective.

${ }^{10}$ Complexity in the meaning that umpredictable events may occur.
} 
of procedural rationality, whenever we consider the complexity of choices made by agents having limited capacity to treat information (Simon, 1976).

Those economic analyses linking network concepts to incentive models ${ }^{11}$ study the decision making process within organizations through the relationships among agents, firms, and networks. These relationships are guided by an incentive model, where the final objective of an action is not considered and where everything is dictated by the environment. About the subject of the activities' coordination, what happens inside the organization is not important to understand what happens outside the organization ${ }^{12}$. We are then talking of the substantive rationality paradigm.

The French conventionalists suggest an economic approach which bases its analysis of the organization upon a procedural approach to rationality (cf. Revue Économique, April 1989; Orléan, 1994). They propose to abandon the dualistic approach of trading society, opposing two pure models of regulation: one where individuals conform to the rational choice theory, and one where individuals follow norms dictated by the rest of the world (the exterior). In this framework, the objective of the economic analysis is slightly modified: what we are looking for is not to analyze a particular social forms, but instead, to understand how a collective logic is formed and which resources it has to use to become stable (Orléan, 1994, p. 16). Real life situations studied by the economist are, most of the time, composite situations where several coordination principles coexist. To analyze such composite situations, the conventionalists combine economic concepts and analyses proposed by the other sciences.

As it is suggested by Eymard-Duvernay (1999, p. 4), rationality is formed by institutions. It is not an universal and natural competence. The institutions form the context of action, which influences the way decisions are made, by selecting and framing appropriate information, as it is shown by the cognitive scientists. Nevertheless, we should not fall into the holistic excess by dictating the elements their behaviour: institutions form the bases of actions but they are not some internalized determinants of behaviour (Eymard-Duvernay, 1999). Organizations are at the basis of relational frameworks, which allow for the emergence of incomplete contracts.

The origin of this "heterodox trend" of political economy comes from the idea that a simple summation of private relationships is not enough to ensure a regular reproduction of the market economy. Economic agents evolve in a trading society, which implies the existence of distinct social relationships from competitive arbitration, to construct itself. The trading society needs conventions and rules to last.

The rules and conventions have several characteristics: they are more ore less interpretable prescriptions and they represent the support for the apprenticeship and collective knowledge. The action and the convention are the construction of meanings. The convention cannot only be considered as a set of words put together.

Conventions are answers to the "how" questions and they are at the same time, models and tools. Consequently, there can be any mechanical conformity. Conventions need interpretation and let the uncertainty be. They widen the individual capacity and help

\footnotetext{
${ }^{11}$ See, for instance, the work of Aoki.

${ }^{12}$ We reason in terms of "external market", to reuse an expression of Favereau (1989a).
} 
agents to save on knowledge. Referring to conventions comes up to approaching scientific questioning in a complex way. As Le Moigne underlined it, when we model complexity, we do not look for the cause of the state in the environment, but for the understanding of agents' behaviour in relation to some projects. Conventionalist view the decision making process as a recursive spiral of the deliberation process, which results in a decision. and of the result as a decision. This recursive spiral (as it appears in a complex approach) leaves enough room to radical uncertainty in the economic way of thinking.

Procedural rationality uses a complex methodology. That is the main reason why it seems difficult to refer to both concepts of rationality within the same framework and to consider that an economic agent can adopt either one to make his decision.

\section{The irreducibility between the substantive and the procedural rationality}

The object of economic analyses, which use substantive rationality, is the best choice among given options. A decision can be taken depending on the optimization criterion. It can also be taken based on procedural rationality focuses, whenever one focuses on the leading to choices, on the construction of possible options, and on the deliberation process. Deliberation is irreducible to a calculus because it partly invents the objects used. We have to understand a decision according to the study of the decision-making' process. The objective of economic analyses is not the same in both cases.

It seems difficult to choose the methodological position of substantive rationality and at the same time, to suppose that the economic agent may sometimes use procedural rationality. It seems, similarly, contradictory to think in terms of procedural rationality and to suppose that the agent could act in terms of substantive rationality. As we have just shown above, the two paradigms define the position of the researcher and, consequently, the object of study he is giving to himself. This does not happen with the economic agent (or his action). Those difficulties can be shown by taking a closer look at the uncertainty concept, which is used in both cases.

We will refer, here, to Kéchidi' study (1998) where he analyses Simon's propositions.

According to Kéchidi, the behaviours would be substantial in simple situations, but procedural in uncertain contexts.

The example chosen by Kéchidi is about road crossing: it is impossible to interpret driving rules at a classical crossroad. Those rules are deontic prescriptions. The behaviour becomes a routine or obeys to an imperative procedure (i.e. traffic lights: stop when it is red, slow when it is orange and pass when it is green...). It can be characterized by the fact that it does not get adapted. In other words, an agent is not allowed to adapt his behaviour in the middle of his action. A deontic rule has such a power of constraint upon the agents' behaviour that autonomy is restricted. Actually, a non-autonomous behaviour is predictable. We do know the components of such a behaviour, and. there is, in fact, only one behaviour, which is consonant with substantive directives.

In some types of road crossing, the agent has the possibility to keep driving around and around even in the presence of other drivers. Now, the agent can appreciate the situation; 
consequently, we are in the framework of procedural rationality (Kéchidi, 1998, pp. 437-438). "The action in the organization proceeds from procedural decisions and substantive decisions" (Kéchidi, 1998, p. 420), because some environments are simple, while other are complex and radically uncertain (Kéchidi, 1998, p. 419).

The Kéchidi's example ends in logical contradictions. We think that it is impossible to suppose that there can be, at the same time, situations without uncertainty and other with radical uncertainty. To deal with the concept of uncertainty, the researcher has two possibilities:

- In one case, he can set give different levels of uncertainty. He can, then, classify situations from the most certain (simple) to the most uncertain (complicated) - we will talk about probabilistic uncertainty (the one compatible with the methodological choice of substantive rationality). The observer must step back from his object of study and look for the causal relationships which govern reality. In these models, the economic agent evaluates the probability of each possible event to determine his choice. As we have seen before, he will use the principle of classical logic, depending on the more or less sophisticated hypotheses about rationality. If the researcher postulates substantive rationality, a complicated situation - that is a situation where information is incomplete or imperfect - will always be analyzed within the framework of the substantive rationality's paradigm, even if this latter is sophisticated (backward induction, common knowledge...). Backward induction models can deal with those actions which take place in uncertain situations and which have been adapted, like the example presented by Kéchidi. There is absolutely no relationship between actions in Kéchidi's example and those which are adapted based on procedural rationality.

- In the other case, the researcher can postulate that uncertainty cannot be quantified, or radical. It is then, impossible to classify situations according to the fact that they are whether simple or complicated. Supposing that there is a possibility of radical uncertainty, means supposing at the same time, that this type of uncertainty happens in every situation ( $c f$. Knight, 1921). In this case, simple situations can never be.

Indeed, every situation is uncertain (even those which first seem to be the simplest ones). Let us take an example in the saga of the king Olaf Haraldsson ${ }^{13}$. The king of Norway and the king of Sweden were fighting over a tiny village. Since the village was not that important, they decided to draw lots for it, instead of starting a battle. The king of Sweden threw the dice and got a six. He was joyful as apparently the village now belonged to him. But the king of Norway threw the dice and got a six as well. The king of Sweden threw the dice again and got a six again. At that point, he told the king of Norway: "So you see, it's not worth going on. You will not get another one." And the king of Norway answered: "There is still a six on the dice and God, my Lord, can let it out once again". He threw the dice and did it so strong that the dice broke, showing the six and the one, which gave him a seven.

This story shows that when we associate fate with probabilities, we are definitely restricted. When we throw a dice, saying that we can get $1,2,3,4,5$ or 6 , is equivalent to

\footnotetext{
${ }^{13}$ Sagas are historical stories written in Iceland around the XIIth century. Some of them are about the Kings of Norway. This story has been reused by Ekeland (1991, p. 198).
} 
have a correct abstract mathematic scheme, but it is not the complete reality. The reality is that we can get a seven. Fate is surprising because it is totally unpredictable (Ekeland, 1991).

Mobilizing procedural rationality forbids to talk about "the rules of substantive decisions".

Let us take another example, the article number 13 of the French constitution stipulates that the President signs the edict. According to Kéchidi, this rule is substantive. But in 1986, one problem the Constitution had not foreseen appeared. The signature of the edict is an obligation or a prerogative the President? When we reason in terms of procedural rationality, it is not the meaning of the rule, which induces its direct application. That is its application, which generates its meaning. In the philosophy of law, Hart talks about of the law-opened texture ${ }^{14}$.

The above list of possibilities is not exhaustive, because, the routine behaviour, which obeys to an imposed procedure, does not exclude the possibility of behaviour not in line.

If by his action, an individual, can takes part in the physical world, by his conscience, he can escape it. The repetitive character of a behaviour tends to hide this dimension, which can at any time introduce a change or a break in a system apparently dominated by causality (Paulré 1995, p. 502). B. Paulré explained: by his thought and according to his level of conscience and his non-submission to habits or other alienation factors, an individual can free himself and keep his distance with the immediate contingencies. This has a meaning only if we admit that thought is not a continuation or a simple reproduction of the sensorimotor world. In fact, thought is a reconstruction, a set of interpretations of the world resting on generalities or a combination of possible events. The freedom and distance to contingencies an individual can have are made possible by the opening and the amplification a logical system may confers. That system eventually becomes a necessary condition for autonomy (Paulré, 1995, p. 502). Many other authors share that point of view. For instance Vallée, who reminds us that, according to Vendryès, the living organism - by acquiring its autonomy from its environment and with regard to it becomes able to enter into uncertain relationships with it. In the case of the human being, this last ability gives him the mental autonomy, which guarantees his free will (Vallée, 1995, p. 504).

In the framework of procedural rationality, we have to admit that the agent still has the possibility to act in a different way, and it is difficult (not to say impossible) to suppose that decisions do exist, which are totally determined by the environment. If it is case, one would have to admit that whenever an agent sits in and drives his car, he gets rid of his human nature to become an automaton, or a "trivial machine" in Morin's words (1977). In the perspective of procedural rationality, we would rather say, "that determinism is not in Nature but in man's mind" (Fourastié, 1995, p. 515). Moreover, there can be facts - belonging to internal or external environment - which escape the observer's attention and which can modify behaviour (alcohol, anger, impatience... at least in the example

\footnotetext{
${ }^{14}$ Hart (1976) or for instance, Jeammaud (1990), and for a detailed study of the rules, Pernin (1994, p. 125 and following).
} 
of driving behaviour on the road). That is what Le Moigne $(1984 ; 1990)$ calls the "aggregativity precept".

But, this consideration should not forbid us to choose a the substantive rationality framework and to consider situations either simple or complicated, since the problem is not the deliberation but the choice among several predetermined occurrences. Only hybridization between the two positions seems largely questionable to us.

Let us sum up these two approaches in Table 1.

TABLE 1. Scientific perspectives reattached to the substantive and procedural rationality compared.

\begin{tabular}{lll}
\hline \multirow{2}{*}{$\begin{array}{l}\text { Objective of scientific } \begin{array}{l}\text { Judgement, objective observation, } \\
\text { practice }\end{array} \\
\begin{array}{l}\text { "pure" world of calculus and quantifi- } \\
\text { cation }\end{array}\end{array}$} & $\begin{array}{l}\text { Subjective understanding, } \\
\text { interpretation, construction, } \\
\text { or reconstruction of reality } \\
\text { enumeration closing the model } \\
\text { Non-evolutionary perspective }\end{array}$ & $\begin{array}{l}\text { What does it make, and why? } \\
\text { Open model } \\
\text { Evolutionary perspective }\end{array}$ \\
\hline Behaviour & $\begin{array}{l}\text { Substantive rationality: } \\
\text { The rationality judgement is about } \\
\text { choice among predetermined options } \\
\text { Given preferences } \\
\text { Research of maximum utility } \\
\text { Solving the problem of multiple } \\
\text { equilibrium }\end{array}$ & $\begin{array}{l}\text { Procedural rationality: } \\
\text { The rationality judgement is about } \\
\text { the construction of the set of possible } \\
\text { options } \\
\text { Structures of variable preferences } \\
\text { Realization of an aspiration level } \\
\text { Several solutions can be approved }\end{array}$ \\
\hline Coordination & $\begin{array}{l}\text { The market } \\
\text { (competition, general equilibrium, }\end{array}$ & $\begin{array}{l}\text { Organizations and institutions } \\
\text { (experience, apprenticeship) }\end{array}$ \\
\hline information by prices) & Radical \\
\hline Obcertainty & Probabilistic & Incomplete \\
\hline Conception of scientific & Positivism & Constructivism \\
knowledge & &
\end{tabular}

\section{From procedural to complex rationality:} The relation "observing system: observed system"

If we refer to the main characteristics of procedural rationality, we can see that:

1. The economic agent cannot make a complete counting (limited rationality, precept of aggregation)

2. He is a part and acts in a whole. He is a part of the environment which has an impact upon his evolution (situated rationality, globalism precept).

3. The agent is guided by his own aims. His behaviour can not be, a priori, explained by his structure, that is by the simple juxtaposition of each element. The structure does not totally determine the behaviour. Different agents may not take the same decision in the same situation (teleological precept). 
We have already seen that it was a first step towards complex analysis, while the substantive rationality is linked to an analytical methodology. With procedural rationality, we are making a first step towards complexity, the second one being to integrate the observer in the modelling.

The Table 2 reviews these two approaches.

TABLE 2. The compared analytical and complex scientific perspectives.

\begin{tabular}{|c|c|c|}
\hline $\begin{array}{l}\text { Conception } \\
\text { of scientific } \\
\text { knowledge }\end{array}$ & Positivism & Constructivism \\
\hline Mode of reasoning & Analytical & Complex \\
\hline Methodology & $\begin{array}{l}\text { Analytical methodology }{ }^{15} \\
\text { 1. The doubt precept. } \\
\text { There is a substantial reality } \\
\text { 2. The analytical precept. Possibility } \\
\text { to fragment each object of analysis } \\
\text { 3. Synthesis precept. } \\
\text { 4. The complete enumeration precept. } \\
\text { We can make a complete counting }\end{array}$ & $\begin{array}{l}\text { Complex system's methodology } 16 \\
\text { 1. The pertinence precept. Objective reality } \\
\text { is not accessible. The researcher defines the } \\
\text { object of his study in relation to his } \\
\text { intention } \\
\text { 2. The precept of aggregation. The researcher } \\
\text { selects facts that seems relevant to him } \\
\text { (as a complete counting is impossible) } \\
\text { 3. Globalism precept. There is an active } \\
\text { and a retroactive effect of the system with its } \\
\text { environment }{ }^{17} \\
4 \text {. Teleological precept. The system is guided } \\
\text { by its own aims }\end{array}$ \\
\hline Epistemology & $\begin{array}{l}\text { Positivist epistemology } \\
\text { Determinist and ontological hypotheses } \\
\text { Analytical modelling's principle } \\
\text { and sufficient reason principle }{ }^{18} \\
\text { Discovering reality } \\
\text { Objects' modelling (basis unit } \\
\text { of an economy: the individual agent) }\end{array}$ & $\begin{array}{l}\text { Constructivist epistemology } \\
\text { Teleological (interpretation of phenomena } \\
\text { in terms of behaviour correspondence and } \\
\text { intentionality) and phenomenological (reality } \\
\text { is not separated from perception) hypotheses } \\
\text { Systemical modelling's principle } \\
\text { and intelligent action principle } \\
\text { Construction of reality } \\
\text { Actions modelling (basis unit of an economy: } \\
\text { the relation between the individual } \\
\text { and his environment) }\end{array}$ \\
\hline
\end{tabular}

\footnotetext{
${ }^{15}$ Cf. Descartes (1946, 1st edn. 1637, pp. 64-66).

${ }^{16}$ Cf. Le Moigne (1984, pp. 42-45). For a detailed comparison of this two methodologies, (cf. Pernin, 1994, pp. 98-103).

${ }^{17}$ Varela, 1989.

${ }^{18}$ Equivalence between cause and effect. If $\mathrm{A}$ is the cause of B, then B can only be caused by A, and so A is the sufficient reason or the certain explication of B.
} 
The procedural rationality paradigm emphasizes several characteristics of the economic agent: limited or bounded rationality, situated rationality, and teleological precept. With complex rationality - as we decided to name it here - the same characteristics are used for the observer (it is the pertinent precept). The observed system (complexity) is of the same nature as the observing system (intelligence): they both are an organization (Le Moigne, 1999, p. 29; von Foerster, 1988).

Reality can not be known from perception. The sight, as Varela or von Foerster described it, gives a good example of the importance of internal references. Varela shows that in reality, a great part of what we perceive comes from the visual cortex itself, from the very place where our own activity takes place. Our nervous system counts 100 millions of sensorial receptors, sensitive to changes in our external environment, and 10000 billions of synapses, sensitive to changes in our internal environment (von Foerster, 1988, particularly p. 59). We are then much more sensitive to changes in our internal environment than to change in our external environment. The definition of what we see depends on our references and on our own experience of the "seeing" activity.

In the representation approach, we look at a the flower and we build an internal image of what the flower is. In the constructivist approach, we renounce to look at the brain with a well-defined information entrance. Therefore, we can not postulate a representation anymore, and we put in parenthesis the objectivity of world. Each observer creates his own world of signification.

What we perceive from our senses is not the external world, but facts used to create an external world by ourselves. This happens by substituting "things we know" to "things we see". This knowledge holds virtual powers. An individual projects an enclosure all around him, whose fends are only the reciprocal of his extended senses. It is the perception topology and in such a situation, topology embraces time (Valéry, 1973, tome I-1193 and 1189, reused by Tabary, 1994, p. 292). As Tabary underlines it, the global result is a constructive reality which surrounds the individual and which is the field of his cognitive activity.

If we go back to economic analysis, we can say that there exists two levels of complexity. A first level when the analysis uses the procedural rationality model and a second one when it internalizes the observer into the study.

The first ideas of research in that direction were proposed, for instance, by Delorme (1995) in his study on the notion of characteristic modes of interaction between the State and the economy.

\section{Conclusion}

Economic action constantly reveals its complexity: irreversibility, progressive nature and uncertainty. The North American founders of pragmatism (Pierce, James or Dewey) used to say that the good way of thinking would be to reject the denial of complexity. Must the economic sciences have a complex gaze? Many authors think so ( $c f$. Delorme, Le Moigne, among others). 
If we define complexity by the fact that uncertainty of a certain type is taken into account - radical uncertainty which cannot be quantified - and if we show that procedural rationality is a first step towards complexity, then, we have to consider that substantial rationality and procedural rationality are two incommensurable notions, which belong to different epistemologic approaches and methodologies.

How do economic theories consider these rationality concept? Some theories use the procedural rationality concept but none internalizes the purpose of the observer's analysis. According to Delorme (1995, p. 4), "that no available theory is capable of articulating the diversity of institutional and organizational patterns of state-economy interactions whose existence is established by careful observation in otherwise market led economies". Let us consider for instance a very classical and complex economic problem of efficient income distribution mechanisms, Le Moigne (2000) argues as follows: "Are we unable to cognitively take into account this empirical fact by arguing that no stable algorithm, which can determine the unpredictable form of the relationship between the GNP and the policy of revenue distribution exists? We know that, by trial and error, by means-end analysis, we can use our own reasoning process to search one step at a time. We cannot predict or pre-determine the "result" of the process (...), but we can describe the procedure, the "how we intent to behave" at each step and on the evolution of the behaviour of the system as whole".

As such, studies conducted on complex rationality in economics - complex rationality viewed as procedural rationality to which we add the modeling of observer's aims - can build the basis for a possible research program on constructivism and complexity.

\section{References}

Bernheim B.D. (1984) Rationalizable strategic behavior, Econometrica 52, pp. 1007-1028.

Boyer R., Orléan A. (1991) Les transformations des conventions salariales entre théorie et histoire. D'Henry Ford au fordisme, Revue Économique, 42 (mars), pp. 233-272.

Chiappori P.A. (1994) Anticipations rationnelles et conventions. In: Orlean A. (Ed.), Analyse économique des conventions. PUF, collection Économie, Paris.

Conein B. (1990) Peut-on observer l'interprétation ? In: Pharo P., Quere L. (Eds.), Les formes de l'action. Éditions de l'École des Hautes Études en Sciences Sociales, Paris, pp. 311-334.

Delorme R. (1995) From first order to second order complexity in economic theorizing. CEPREMAP, Paris. Research document.

Delorme R. (1997) Évolution et complexité : l'apport de la complexité de second ordre à l'économie évolutionnaire, Économie Appliquée, tome $\mathbf{L}, \mathrm{n}^{\circ} 3$, pp. 95-120.

Demange G., Ponsard J.P. (1994) Théorie des jeux et analyse économique. PUF, collection Économie, Paris.

Dennett D. (1978) Intentional system. In: Brainstorms: philosophical essays on mind and psychology. Cambridge, Mass., MIT Press, pp. 3-22 (French translation, 1984, Système Intentionnels, No. 1, pp. 55-80).

Descartes R. (1946) Discours de la Méthode, with an introduction of Gilson E. (1st edn., 1637). Librairie philosophique J. Vrin, Paris.

Dewey J. (1967) Logique, la théorie de l'enquête. PUF, Paris (1st edn., 1938). 
Dupuy J.P. (1992) Introduction aux sciences sociales, logique des phénomènes collectifs. Édition marketing, collection Ellipse, Paris, 297 p.

Ekeland I. (1991) La mathématisation du hasard. In: Le hasard aujourd'hui, collective book. Éditions du seuil, collection point sciences, Paris, pp. 195-207.

Eymard-Duvernay F. (1999) L'évolution des conventions salariales. Séminaire Lereps 3 juin 1999, Université Toulouse 1.

Favereau O. (1989a) Marchés internes, marchés externes, Revue Économique, 40 (2), pp. 273 328.

Favereau O. (1989b) Organisation et marché, Revue Française d'Économie, IV (1), pp 65-96.

Favereau O. (1997) Approche de la décentralisation par l'économie des conventions. In: Affichard J. (Ed.), Décentralisation des organisations et problèmes de coordinations : les principaux cadres d'analyse. L'Harmattan, Paris, pp. 47-55.

Fourastié J. (1995) Le dialogue entre Jean Fourastié et Pierre Vendryès à la recherche de l'homme, Revue Internationale de Systémique, 9 (5), pp. 513-516.

Guerrien B. (1997) Dictionnaire d'analyse économique. La Découverte, Repères, Paris.

Guesnerie R. (1989) An exploration of the educative justification of the rational expectations hypothesis. Mimeo, DELTA, Paris.

Harsanyi J. (1967-1968) Games with incomplete information played by "Bayesian Players", part I, II and III, Management Science, 14, pp. 159-182, 320-334, 486-502.

Hart H.L.A. (1976) Le concept de droit. Publications des Facultés Universitaires Saint-Louis Bruxelles, (1st edn. 1961), 314 p.

Isla A. (1999) Le statut de l'acteur dans les analyses économiques, Cahiers de recherche du Lereps. Université des sciences sociales de Toulouse.

James W. (1908-1968) Le Pragmatisme. Flammarion, Paris.

Jeammaud A. (1990) La règle de droit comme modèle, Chronique Recueil Dalloz, ${ }^{\circ}$ XXXIV, pp. 199-210.

Kéchidi M. (1998) Rationalités et contextes de décisions : un retour sur H. Simon, Revue Internationale de Systémique, 12 (4-5), pp. 419-440.

Knight F. (1921) Risk, uncertainty and profit. Mifflin, New York.

Le Moigne J.L. (1984) La théorie du système général, théorie de la modélisation. PUF, collection Systèmes-Décisions, Paris, (1st edn. 1977), 320 p.

Le Moigne J.L. (1990) La modélisation des sytèmes complexes. Dunod, Bordas, Paris.

Le Moigne J.L. (1999) Sur la modélisation de la complexité. In: Morin E., Le Moigne J.L. (Eds.), L'intelligence de la complexité. L'Harmattan, Paris, pp. 269-325.

Le Moigne J.L. (2000) Recursive and teleological rationality involved in the modeling process of self-organizing socio-economic systems. Research document, GRASCE-GREQAM-CNRS, Aix-Marseille University.

Lewis D.K. (1969) Convention: a Philosophical Study. Havard University Press, Cambridge (USA).

Nash J.F. (1951) Noncooperative games, Annals of Mathematics, 54, pp. 289-295.

Mongin P. (1986) Simon, Stigler et les théories de la rationalité limitée, Information sur les sciences sociales, 25 (3), pp. 555-606.

Morin E. (1977) La méthode, Tome 1 : La Nature de la Nature, Tome 2 : La Vie de la Vie. Éditions du Seuil, collection Point anthropologie, Sciences humaines, Paris. 
Munier B., Orléan A. (1993) Rapport sur les liens entre sciences cognitives et sciences économiques et de gestion, Section Économie et Société du Comité National, Centre National de la Recherche Scientifique, 49 p.

Orléan A. (1994) Analyse économique des conventions. PUF, Paris.

Orléan A. (1997) Jeux évolutionnistes et normes sociales, Économie Appliquée, tome L (3), pp. 177-198.

Paulré B. (1995) Causalité et économie, Revue Internationale de Systémique, 9 (5), pp. 495502.

Pernin A. (1994) Réglementation et organisation des règles de concurrence dans l'Union européenne. Thèse de doctorat de science économique, Université de Toulouse-I.

Pernin J.L. (1998) L'acteur économique. Cahiers du Lereps, Université de Toulouse-I.

Quinet C. (1994) Herbert Simon et la rationalité, Revue française d'économie, IX (1), pp. 133181.

Renault M. (1997) Pragmatisme et institutionnalisme : des fondements épistémologiques et méthodologiques pour l'évolution en économie, Économie Appliquée, tome L (3), pp. 23-52.

Revue Économique (1989a) L'économie des conventions, 40 (numéro spécial 2), pp. 273-328.

Schelling T. (1960) Strategy if conflict. Oxford University Press, Oxford.

Simon H.A. (1955) A behavioral model of rational choice, Quartely Journal of Economics, 69, (February), pp. 99-118 (used in 1983b, 2).

Simon H.A. (1976) From substantive to procedural rationality. In: Latsis J.P. (Ed.), Method and appraisial in economics. Cambridge University Press.

Tabary J.C. (1994) Introduction à la méthode de Paul Valéry, Revue Internationale de Systémique, 8 (3), pp. 287-306.

Valéry P. (1973) Cahiers, tomes I et II. Bibliothèque de la Pléiade, Gallimard, Paris.

Vallée R. (1995) Vendryès et la théorie des systèmes, Revue Internationale de Systémiquen, 9 (5), pp. 503-505.

Varela F. (1989) Autonomie et connaissance. Essai sur le vivant. Éditions du Seuil, collection la couleur des idées, Paris. (French translation: Bourgine P., Dumouchel P., from: Principles of biological autonomy (1979) North-Holland, Amsterdam).

Von Foerster H. (1988) La construction d'une réalité. In : Watzlawick P. (Ed.), L'invention de la réalité, (Contributions au constructivisme). Seuil, collection la couleur des idées, Paris, pp. 45-69.

Weinberg A. (1995) À quoi jouent les acteurs, les théories de l'action dans les sciences humaines, Sciences humaines, No. 9 (hors série).

Winter S.G. (1994) Natural selection and evolution. In: Eatwell J., Milgate M., Newman P. (Eds.), The new Palgrave, A dictionnary of economics, Vol. 3. The Macmillan Press limited, London, pp. 614-615. 